\title{
Canopy analysis as a technique to characterize defoliation intensity on Sandhills range
}

\author{
M.S. MILLER-GOODMAN, L.E. MOSER, S.S. WALLER, J.E. BRUMMER, AND P.E. REECE
}

Authors are associate professor, Department of Agronomy and Soils, Auburn University, Auburn, Ala. 36849; professor, Department of Agronomy, University of Nebraska, Lincoln, Neb. 68583; associate dean, Institute of Agriculture and Natural Resources, University of Nebraska, Lincoln, Neb. 68583; research scientist, Mountain Meadow Research Center, Colorado State University, Gunnison Colo. 81230; associate professor, Panhandle Research and Extension Center, University of Nebraska, Scottsbluff, Neb. 69361. At the time of the research the senior author was post-doctoral research associate, University of Nebraska, Lincoln, Neb. 68583.

\begin{abstract}
Characterization of relationships between grazing and vegetation responses is difficult. Rapid and accurate measurement of pasture canopy characteristics would help clarify these relationships if canopy changes are directly related to grazing variables. The objectives of this study were (1) to evaluate use of the LI-COR LAI-2000 for quantification of changes in canopy density and architecture in response to defoliation by cattle, (2) to determine if changes in leaf area index (LAI) measured with the LAI-2000 are related to stocking rate, and (3) to determine advantages and drawbacks of the LAI-2000 for monitoring grazing impacts on canopy density and architecture. Leaf area index and mean foliage tilt angle were measured before and after defoliation by cattle (Bos taurus L.) in June, July, and August under 9 grazing treatments on Nebraska Sandhills range. Differences in LAI could be attributed to certain grazing treatments at various points throughout the season. Grazing treatment had little impact on mean foliage tilt angle. Change in LAI $(\Delta \mathrm{LAI})$ had a significant negative relationship with stocking rate $(\mathbf{P} \leq \mathbf{0 . 0 0 0 1})$. The relationship detected for $\Delta \mathrm{LAI}$ versus stocking rate predicted LAI reductions of between 0.14 and 0.40 for the range of stocking rates studied; stocking rate accounted for $62 \%$ of the decrease in LAI caused by grazing. When configured for the Sandhills canopy, the LAI-2000 provided a rapid and precise method for quantification of the degree of defoliation associated with grazing.
\end{abstract}

Key Words: LI-COR LAI-2000, leaf area index, foliage tilt angle

Proper herbage utilization is one of the most important considerations in range management and numerous methods have been developed for its measurement (Cook and Stubbendieck 1986). Many of these methods have been criticized because they estimate a quantity that is no longer present to measure

\footnotetext{
University of Nebraska Journal Series No. 11925.

Funding for this project was received through a grant from the Anna H. Elliot Fund, Institute of Agriculture and Natural Resources, University of NebraskaLincoln.

Manuscript accepted 4 Oct. 1998.
}

La caracterización de las relaciones entre el apacentamiento y la respuesta de la vegetación es difícil. Si los cambios de la copa de la pradera estan directamente relacionados a variables de apacentamiento, la medición rápida y acertada de las características de la copa podría ayudar a clarificar estas relaciones. Los objetivos de este estudio fueron: (1) evaluar el uso del LI-COR LAI-2000 para cuantificar los cambios en la densidad y arquitectura de la copa en respuesta a la defoliación por ganado, (2) determinar si los cambios en el índice de área foliar (IAF) medidos con el LAI-2000 estan relacionados a la carga animal y (3) determinar las ventajas y desventajas del LAI-2000 para monitorear los impactos del apacentamiento en la denisidad y arquitectura de la copa. Se midieron el índice de área foliar y el ángulo promedio de inclinacion del forraje antes y después de la defoliación por ganado (Bos taurus L.) durante Junio, Julio y Agosto bajo 9 tratamientos de apacentamiento en los pastizales "Nebraska Sandhills". Diferencias en IAF pudieron ser atribuidas a ciertos tratamientos de apacentamiento en varios puntos a través de la estación. Los tratamientos de apacentamiento tuvieron poco impacto en el ángulo promedio de inclinación del forraje. Los cambios en IAF ( $\triangle \mathrm{IAF}$ ) tuvieron una relación negativa significativa con la carga animal $(\mathbf{P} \leq \mathbf{0 . 0 0 0 1})$. La relación detectada para $\triangle \mathrm{IAF}$ versus carga animal predijó reducciones de IAF de entre 0.14 y 0.40 para el rango de cargas animal estudiadas. La carga animal explicó el $62 \%$ de la disminución del IAF causada por apacentamiento. Cuando el LAI-2000 fue configurado para la copa de los "Sandhills" el LAI-2000 proveyó un método rápido y preciso para cuantificar el grado de defoliación asociado con el apacentamiento.

directly and give only a rough approximation as to the degree of defoliation (Heady 1949, Heady and Child 1994, Sharp et al. 1994). Also, Hyder (1954) pointed out that sources of variation in site factors and plant communities within rangeland pastures cause uneven grazing distribution and prevent a direct plant physiological interpretation of utilization percentages. Alternative approaches proposed for several rangeland types measured utilization based on herbage residue rather than herbage removed (Bentley and Talbot 1951, Heady 1956, Bement 1969, Schmutz 1971). A desirable compromise, par- 
ticularly for research studies, would be a rapid, nondestructive method to accurately and precisely quantify a plant parameter that could be measured before and after a grazing event, and related directly to both stocking rate and defoliation impacts on plant function.

Brown and Blaser (1968) suggested that the development of the leaf area index (LAI) concept in pasture growth and management would bring together physical and physiological properties of plant communities to help clarify the complicated relationship between pasture growth and utilization. In a series of studies, Parsons et al. (1983a, 1983b) used LAI to maintain canopies of perennial ryegrass swards in 'leniently'-grazed $(\mathrm{LAI}=3.0)$ and 'hard'-grazed (LAI = 1.0) conditions to determine the balance between photosynthesis, animal intake, and losses of vegetative matter. However, few measures of LAI have been reported for native range canopies.

We adapted a relatively new technology in nondestructive plant canopy analysis (Welles and Norman 1991) to quantify changes in canopy density (leaf area index) and architecture (mean foliage tilt angle) before and after defoliation by cattle for an array of grazing treatments on Sandhills range. Our objectives were (1) to evaluate use of the LI-COR LAI-2000 ${ }^{1}$ for quantification of canopy changes in response to defoliation by grazing herbivores, (2) to determine if changes in leaf area index (LAI) measured with the LAI2000 are related to stocking rate, and (3) to determine advantages and disadvantages of the LAI-2000 for monitoring grazing impacts on canopy density and architecture.

\section{Materials and Methods}

\section{Study Site}

Data were collected June-October 1991 at the University of Nebraska Gudmundsen Sandhills Laboratory located 11 $\mathrm{km}$ northeast of Whitman, Neb. Soils are Valentine fine sands (mixed, mesic Typic Ustipsamments) derived from eolian sand parent material. Vegetation is dominated by mid and tallgrass including sand bluestem \{Andropogon gerardii var. paucipilus (Nash) Fern.\}, prairie sandreed

${ }^{1}$ LI-COR, Inc., Box 4425, 4421 Superior St., Lincoln, Neb. 68504 U.S.A.
\{Calamovilfa longifolia (Hook.) Scribn.\}, and little bluestem $\{$ Schizachyrium scoparium (Michx.) Nash\}. Other species common at the site are prairie junegrass \{Koeleria macrantha (Ledeb.) Schult.\}, sand dropseed \{Sporobolus cryptandrus (Torr.) Gray\}, needle-and-thread (Stipa comata Trin. \& Rupr.), hairy grama (Bouteloua hirsuta Lag.), western ragweed (Ambrosia psilostachya DC.), and sedges (Carex spp.).

Precipitation recorded for the periods Jan-March, April-September, and October-December 1991 were 111, 420, and $93 \mathrm{~mm}$, respectively. These values represented $159 \%, 100 \%$, and $133 \%$ of the 30-year average precipitation recorded at the NOAA site $10 \mathrm{~km}$ northeast of the Gudmundsen Laboratory (Reece et al. 1996).

\section{Treatments}

Grazing treatments consisted of 4 to 7-day, mid-month grazing periods in (1) June, (2) July, (3) August, (4) June and July, (5) June and August, (6) July and August, or (7) June, July, and August, (8) October, and (9) ungrazed controls (Table 1). Treatments were replicated 3 times over 24, 1.0-ha paddocks (Reece et al. 1996). Grazing treatments were applied to the same paddocks during 4 consecutive years beginning in 1988 . Cattle were weighed after an overnight stand without food and water and allocated to treatments by weight. One animal unit (AU) was equal to $454 \mathrm{~kg}$ of yearling cattle. Seasonal stocking rates were set each year at $60 \%$ utilization of current year herbage as estimated in pastures grazed only in June. Seasonal stocking rates were equal among treatments and divided equally over multiple grazing periods. In 1991 the seasonal stocking rate was $1.62 \mathrm{AUM} \mathrm{ha}^{-1}$ and grazing periods were 3-4 days.

Three permanent $50-\mathrm{m}$ transects were randomly located in each pasture and in 3 ungrazed areas contiguous to the pastures. Five, $1-\mathrm{m}^{2}$ quadrats were randomly located in permanent positions along each transect and used as the locations for canopy analysis measurements.

\section{Canopy Analysis}

Leaf area index and mean inclination of the foliage were measured indirectly at each of the $15,1-\mathrm{m}^{2}$ quadrats in each pasture using the LAI-2000 immediately before (pre-grazing) and after (post-grazing) defoliation events in June, July, and August. These measurements were made whether or not a pasture was grazed at those times. Measurements were also made in ungrazed areas pre- and postgrazing. In October, pre-grazing measurements were made in all areas but since the canopy was senescent, postgrazing measurements were made only in pastures grazed at that time.

The LAI-2000 consists of an optical sensor and control box/datalogger. The sensor incorporates fisheye optics to project a hemispheric image of the canopy onto 5 silicon detectors that are arranged in concentric rings. The control box records the sensor's data and performs the calculations necessary for determining LAI and mean foliage tilt angle; standard errors are also calculated for both parameters. The technique combines a measurement of sky brightness from a leveled sensor above the canopy with a second measurement taken beneath the canopy with the sensor again viewing skywards. Attenuation of diffuse sky radiation is measured simultaneously at 5 zenith angles $\left(7^{\circ}, 23^{\circ}\right.$,

Table 1. Treatment number, stocking rate/grazing period, and dates of mid-month grazing periods Gudmundsen Sandhills Laboratory, Whitman Neb., June-October 1991.

\begin{tabular}{|c|c|c|c|c|c|}
\hline \multirow[t]{2}{*}{ Treatment number } & \multirow{2}{*}{$\begin{array}{l}\text { Stocking rate/ } \\
\text { grazing period }\end{array}$} & \multicolumn{4}{|c|}{ "Mid-month grazing periods } \\
\hline & & $\begin{array}{l}\text { Mid- } \\
\text { June }\end{array}$ & $\begin{array}{l}\text { Mid- } \\
\text { July }\end{array}$ & $\begin{array}{l}\text { Mid- } \\
\text { August }\end{array}$ & $\begin{array}{c}\text { Mid- } \\
\text { October }\end{array}$ \\
\hline (1) & $\begin{array}{c}--\left(\text { AUM ha }^{-1}\right)-- \\
1.62\end{array}$ & X & Grazin & frequenc & - - - - - - \\
\hline (2) & 1.62 & & $\mathrm{X}$ & & \\
\hline (3) & 1.62 & & & $\mathrm{X}$ & \\
\hline (4) & 0.81 & $\mathrm{X}$ & $\mathrm{X}$ & & \\
\hline (5) & 0.81 & $\mathrm{X}$ & & $\mathrm{X}$ & \\
\hline (6) & 0.81 & & $\mathrm{X}$ & $\mathrm{X}$ & \\
\hline (7) & 0.54 & $\mathrm{X}$ & $\mathrm{X}$ & $\mathrm{X}$ & \\
\hline (8) & 1.62 & & & & $\mathrm{X}$ \\
\hline (9) & 0 & & & & \\
\hline
\end{tabular}


$\left.38^{\circ}, 53^{\circ}, 68^{\circ}\right)$. The ratio of each ring's signals (below to above) is then assumed to be equivalent to the canopy's gap fraction (the fraction of sky visible through the canopy) at that ring's viewing angle. By measuring attenuation at several angles from the zenith, foliage orientation information can also be obtained (Welles and Norman 1991).

For this study, the LAI-2000 was configured to calculate LAI and mean tilt angle with 1 above-canopy and 5 belowcanopy readings on the top-left to bottom-right diagonal of each of the 5 quadrats located along the 3 transects in each pasture. Thus, average LAI or mean tilt angle for a given pasture were each based on 15 separate determinations. Multiple below-canopy measurements are usually required to achieve a suitable spatial average for a site. A simple procedure was initially used to determine the number of below-canopy readings necessary for $95 \%$ confidence that the true LAI mean was within $\pm 10 \%$ of the measured LAI. LAI determinations were made based on 6 below-canopy readings in 10 randomly selected areas then coefficients of variation determined as (standard error of the LAI measurements)/ average LAI. The coefficient was compared to published guidelines (LI-COR, Inc. 1993) to determine the number of below-canopy readings necessary.

The view of the sensor often needs to be restricted to mask out the operator or the sun. A canopy with large gaps may require a narrowed field of view so that gaps and canopy can be correctly integrated. Opaque masks that obscure $90^{\circ}$, $180^{\circ}, 270^{\circ}$, or $315^{\circ}$ can be placed onto the sensor to modify the field of view. View restriction to $45^{\circ}$ was required for this study to mask the operator, and because the Sandhills canopy is heterogenous and has significant gaps (LICOR, Inc. 1993). Also, the part of the canopy visible to the sensor should be shaded since the more sunlit leaves the sensor detects, the larger the underestimate of LAI. For this study, all measurements were made between 0430-0930 hours or 1630-2030 hours to take advantage of diffuse sunlight, and shadows cast by the operator that acted to shade the sensor and canopy when the sun was low in the sky. Slope effects on LAI estimates were minimized by choice of view cap (restriction to $45^{\circ}$ ) and by consistent orientation of the sensor along the contour for both below and above readings (LI-COR, Inc. 1993).

\section{Data analysis}

Pre- and post-grazing LAI and mean foliage tilt angle values were analyzed within months (June-October) using general linear models analysis of variance (SAS Institute Inc., 1990). Mean differences were separated using Fischer's protected LSD at $\mathrm{P}=0.05$. Coefficient of variation (CV) and analysis of residual variation $\left\{\sigma^{2} \mathrm{Tmt}^{*} \mathrm{Blk}=\right.$ $\left.\sigma_{\text {Pasture }}^{2}+\left(\sigma_{\text {Sampling }}^{2} / \mathrm{n}\right)\right\}$ over grazing treatments within pre- and post-grazing measurements were calculated as indices of sample (n) adequacy (Kleinbaum and Kupper 1978). Sample number was considered adequate when the CV was less than $10 \%$. Change in LAI ( $\Delta$ LAI) was calculated for each pasture as the difference in LAI before and after each grazing use period:

$\Delta \mathrm{LAI}=\mathrm{LAI}_{\text {post-grazing }}-\mathrm{LAI}_{\text {pre-grazing }}$

Analysis of variance revealed no date $\mathrm{x}$ stocking rate interaction so data were pooled over date for further analysis of the relationship between $\Delta$ LAI and

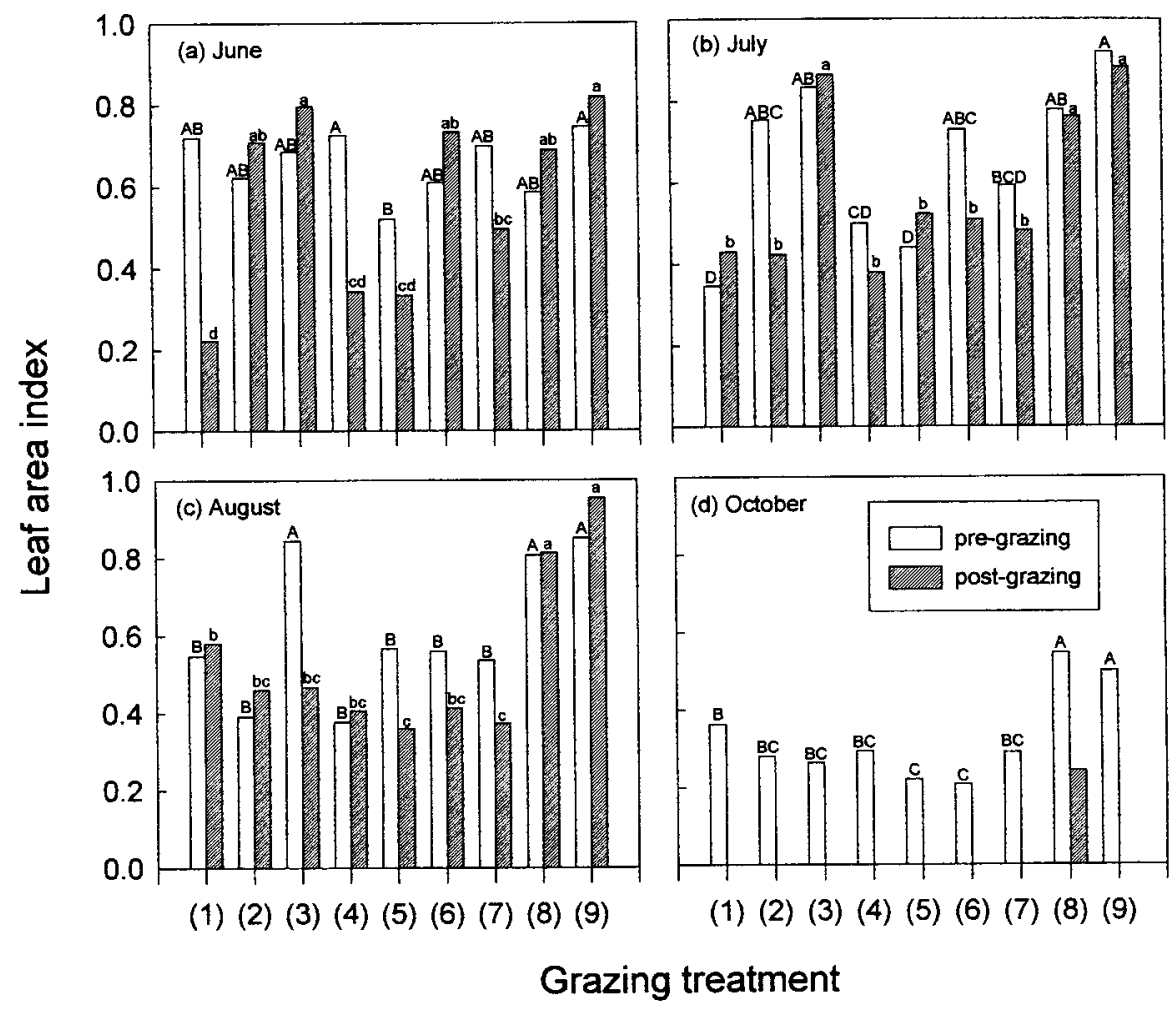

Fig. 1. Pre-grazing (means with upper case letters) and post-grazing (means with lowercase letters) leaf area index values for Sandhills range exposed to 8 grazing strategies or ungrazed, June-October 1991. Means with the same letter within pre-grazing or post-grazing measurements are not significantly different $(\mathbf{P}<0.05)$. Treatment designations: (1) grazed mid-June only; (2) grazed mid-July only; (3) grazed mid-August only; (4) grazed both mid-June and mid-July; (5) grazed both mid-June and midAugust; (6) grazed both mid-July and mid-August; (7) grazed mid-June, mid-July, and mid-August; (8) grazed mid-October only; (9) not grazed. 
Table 2. Mean coefficients of variation (CV) and standard deviations (SD) for leaf area index (LAI) and mean foliage tilt angle (MTA) measured with the LI-COR LAI-2000, Gudmundsen Sandhills Laboratory, Whitman Neb., June-October 1991.

\begin{tabular}{lcccc}
\hline \hline & June & July & August & October \\
\hline LAI & $\ldots \ldots \ldots(\mathrm{CV}(\mathrm{SD}), \%) \ldots \ldots \ldots$ & \\
\hline pre-grazing & $7.5(0.5)$ & $6.6(0.7)$ & $7.0(0.9)$ & $9.1(3.5)$ \\
post-grazing & $7.5(1.6)$ & $7.6(1.1)$ & $8.3(1.4)$ & 11.4 \\
MTA & & & & \\
pre-grazing & $1.9(0.5)$ & $2.2(0.9)$ & $2.3(0.7)$ & $3.7(1.4)$ \\
post-grazing & $3.2(1.5)$ & $2.3(0.7)$ & $2.3(0.6)$ & 6.2 \\
\hline
\end{tabular}

years, or ungrazed sites (Fig. 1a).

Canopy analysis with the LAI-2000 also allowed detection of differences in LAI as pastures entered the dormant season. As expected, ungrazed areas had higher LAI than any of the grazed pastures after the final grazing event in October (Fig. 1d). However, pastures grazed only in June (1) at the full seasonal stocking rate had higher LAI in October compared to pastures grazed twice at $1 / 2$ the seasonal stocking rate in June and August (5) or in July and August (6, Fig. 1d).

Knight (1973) recognized the influence of leaf area on ecosystem processes, particularly primary productivity, and followed total green LAI of shortgrass range in Colorado over a single season. He reported LAI values between 0.1 and 0.6 and showed slightly higher leaf area attrition on heavily ( 0.7 ha per yearling month) versus lightly (1.4 ha per yearling month) grazed shortgrass pastures after 30 years of summer grazing (1 May to 31 October). Welles and Norman (1991) measured LAI between 1.0 and 3.5 for tallgrass prairie plots in Kansas. In this study, mean LAI measured with the LAI-2000 ranged between 0.75 and 1.0 for ungrazed Sandhills canopies from June through August (Fig. 1a, b, c). In grazed canopies, mean LAI values as low as 0.22 were measured (Fig. 1a).

\section{Mean Foliage Tilt Angle}

Grazing treatments had little impact on mean foliage tilt angle. Monthly mean foliage tilt angle decreased from a range of $62-69^{\circ}$ in June to $56-64^{\circ}$ in October. Decrease in foliage angle was most likely a result of continuous canopy senescence throughout the season as actively growing species changed from cool- to warm-season. Foliage angle values obtained in this study were similar to those reported by Smith et al. (1977) for foliage inclination angle of actively-growing western wheatgrass \{Pascopyron smithii (Rydb.) A. Löve\}. Average foliage inclination angles in that study were $68^{\circ}$ and $66^{\circ}$, respectively, using the orthogonal projection and Fredholm integral equation methods.

\section{Sample Adequacy}

Coefficients of variation calculated for LAI and mean foliage tilt angle averaged over grazing treatments in June, July, or August were consistently less than $10 \%$ for LAI and $4 \%$ for tilt angles (Table 2). Coefficients of variation for both parameters increased as the canopy reached senescence but exceeded 10\% only for post-grazing LAI measurements in October. Predicted residual variation (pasture + sampling) was reduced $64 \pm$ $8.6 \%$ by a 15 -fold increase in sample size ( $\mathrm{n}=1$ to 15 LAI measurements per pasture) over all dates (Fig. 2). Increasing sample number to $30 \mathrm{LAI}$ measurements per pasture only reduced predicted residual variation by an additional $6.7 \pm 2.3 \%$ over all dates.

\section{$\triangle L A I$ versus Stocking Rate}

The Pearson correlation coefficient between $\triangle \mathrm{LAI}$ and stocking rate was -0.78 (ASE $=0.51)$. A significant $(\mathrm{P}<0.001)$ quadratic trend detected for $\Delta$ LAI versus stocking rate (Fig. 3) predicted decreases in LAI between 0.14 and 0.40 for the range of stocking rates studied June through August. Stocking rate accounted for $62 \%$ of the decrease in LAI after grazing events. Thus, $\triangle \mathrm{LAI}$ measured with the LAI-2000 appears to have a moderate to strong relationship to stocking rate and would be useful as an index of pasture-level defoliation intensity of Sandhills canopies by cattle.
Sequential, non-destructive measurements of canopy disappearance have been used previously to measure relative palatability of grasses and legumes under grazing. In one study, Stringer et al. (1995) compared non-destructive techniques to follow changes in canopy volume of space-planted, endophytefree tall fescue (Festuca arundinacea Schreb.) plants as an indication of grazing activity and animal preference, but similar relationships were not studied in a solid sward or related to stocking rate.

\section{Advantages and Drawbacks}

Average measurement time per pasture using the LAI-2000 was 20 min., including time required to locate transect markers and move from quadrat to quadrat. In retrospect, analysis of residual variation indicated that as few as 10 LAI measurements per pasture may have been adequate for this rangeland type, further reducing measurement time per pasture. In contrast, leaf area measurements on shortgrass range reported by Knight (1973) using the nondestructive point-quadrat technique in 0.5 -ha plots required 18 hours of labor for 1 LAI determination. Time required to complete 6 of the non-destructive techniques in the study by Stringer et al. (1995) ranged between 7 and $10 \mathrm{~min}$. to set up and measure a single plant. For a seventh technique studied by Stringer et al. (1995), the table method, 2 persons could measure and record canopy diameter and height on 70 plants in $10 \mathrm{~min}$. but the apparatus did not appear suited for easy transport between pastures, particularly in terrain such as that found in Sandhills range. In contrast, the LAI2000 is lightweight, portable, and easily worn by a single operator while traversing large areas. The LAI-2000 also appears more suited for characterization of canopy responses to grazing in a heterogenous plant community such as that found on native range.

Canopy measurements were slower on mornings following a heavy dew since it was difficult to keep water droplets from falling on the sensor when belowcanopy readings were made. Frequent stops were necessary to clean the sensor lens before measurements could be continued within a pasture. This difficulty could be circumvented by waiting until the dew dries, but by that time, the angle of the sun may be such that adequate 


\section{Conclusions}

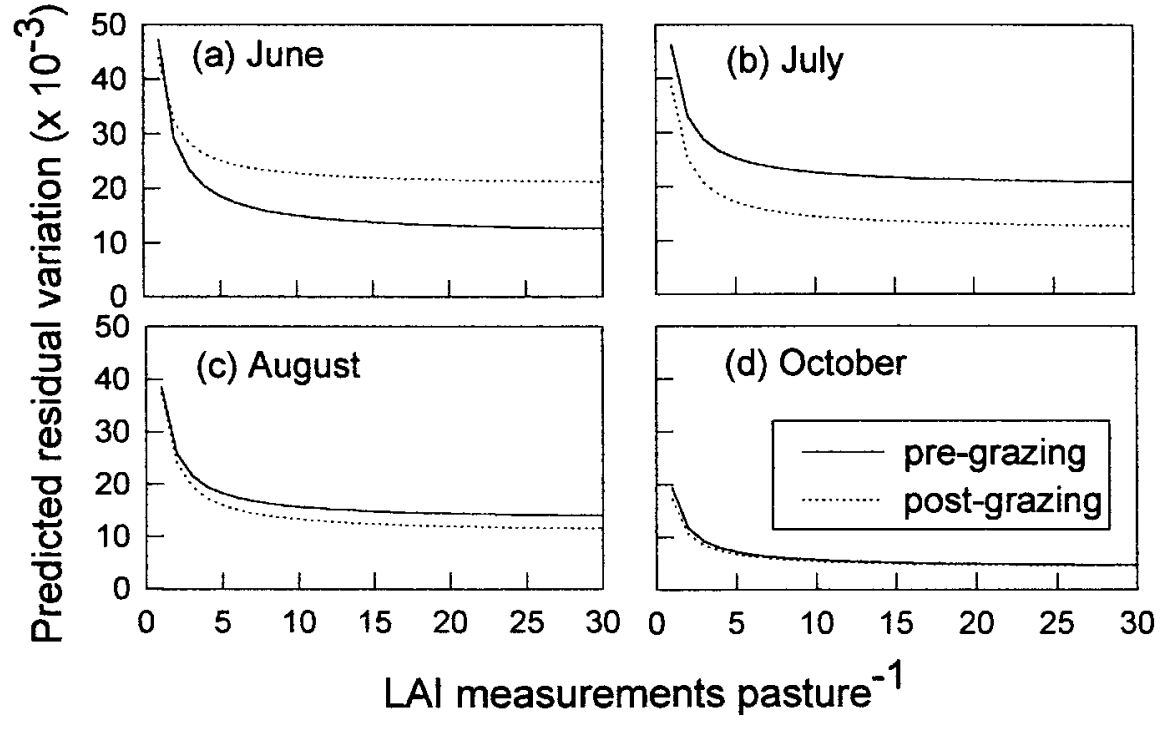

Fig. 2. Predicted residual variation for pre-grazing and post-grazing leaf area index (LAI) values based on between 1 and 30 LAI measurements per pasture (a) June, (b) July, (c) August, (d) October 1991.

shade becomes the limiting factor. Alternatively, measurements could be made only in the late afternoon and evening. Either of these options reduces the potential number of areas measured per day. In this study, it was possible to measure all 24 pastures and ungrazed areas within 36 hours of cattle removal.

Another relationship explored was the strength of the relationship between mean pasture production and mean pregrazing pasture LAI obtained with the LAI-2000 June through October. Pasture production information had been obtained immediately prior to grazing for studies conducted in the same pastures (Reece et al. 1996). The Pearson correlation between pre-grazing pasture production and mean LAI was moderate, however, the prediction model developed to relate LAI to pre-grazing biomass accounted for less than $50 \%\left(\mathrm{r}^{2}\right.$ $=0.43$ ) of the variation in pasture production. Harmoney et al. (1997) compared predictive strength of several well-established indirect methods for estimation of pasture biomass to that of the LAI-2000 for homogeneous swards of warm- and cool-season grasses in Iowa. They reported an overall $\mathrm{r}^{2}=0.32$ for the regression equation developed using LAI-2000 readings vs. $\mathrm{r}^{2}=0.61$, 0.63 , and 0.58 respectively for readings with the modified Robel pole, rising plate meter, and canopy height stick. Their conclusion was that established methods for biomass estimation had greater accuracy than the LAI-2000. Our results with this relationship on Sandhills range support their observation.
When configured for the Sandhills canopy, the LAI-2000 provided a rapid, precise method for quantification of foliage density reduction and recovery rates in response to grazing at different levels or dates throughout the season. Although reduction in whole-plant photosynthesis following defoliation is not necessarily proportional to leaf area or biomass removal, recovery of wholeplant photosynthetic capacity is dependent on the rate at which new photosynthetic surfaces are produced to an equal or greater extent than compensatory photosynthesis (Briske and Richards 1995). Thus, leaf area index LAI measurements could be made at closelyspaced intervals between defoliation events to determine leaf area recovery rates under different grazing treatments. This may be particularly useful in research studies where accurate and precise sampling is required to relate specific grazing treatments to vegetation response. While predictive strength of the relationship between LAI and pasture biomass was moderate at best in this study, further work is needed with the LAI-2000 in various native range canopy types to determine if LAI and

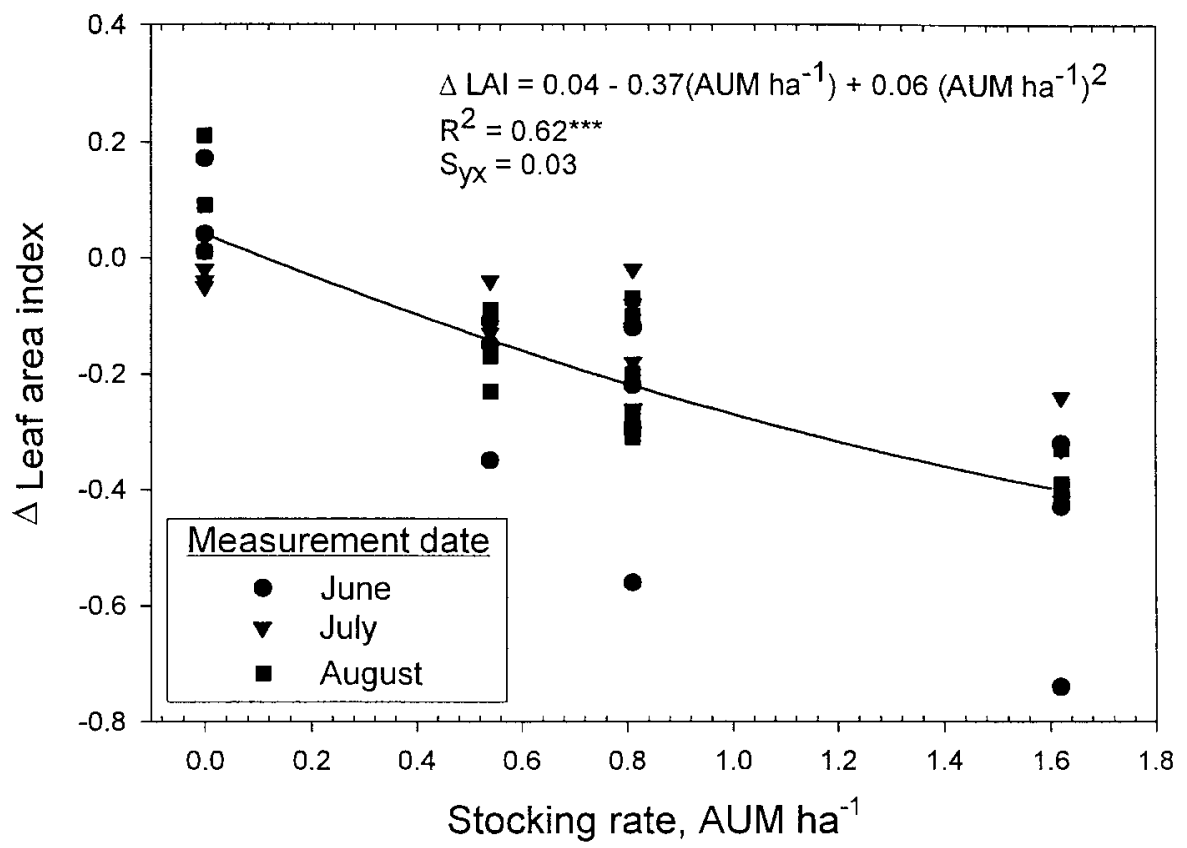

Fig. 3. Relationship between change in leaf area index following grazing versus stocking rate for Sandhills range. The regression equation was developed from measurements made mid-June (circle), mid-July (down triangle), and mid-August (square) 1991. 
mean tilt angle (MTA) are useful in interpretation of physiological responses to various grazing strategies at the plant community level. This application could offer significant advantages in the study of grazing management and warrants further investigation in additional native grassland canopy types.

\section{Literature Cited}

Bement, R.E. 1969. A stocking-rate guide for beef production on blue-grama range. J. Range Manage. 22:83-86.

Bentley, J.R. and M.W. Talbot. 1951. Efficient use of annual plants on cattle ranges in the California foothills. USDA Circ. 870

Brown, R.H. and R.E. Blaser. 1968. Leaf area index in pasture growth. Herb. Abstr. 38:1-9.

Briske, D.D. and J.H. Richards. 1995. Plant responses to defoliation: A physiological, morphological, and demographic evaluation. p. 635-710 In: D.J. Bedunah and R.E. Sosebee (eds.) Wildland plants: Physiological ecology and developmental morphology, Soc. for Range Management, Denver, Colo.

Cook, C.W. and J. Stubbendieck. 1986. Range research: Basic problems and techniques. Soc. for Range Management, Denver, Colo.
Harmoney, K.R., K.J. Moore, J.R. George, E.C. Brummer, and J.R. Russell. 1997. Determination of pasture biomass using four indirect methods. Agron. J. 89:665-672.

Heady, H.F. 1949. Methods of determining utilization of range forage. J. Range Manage. 2:53-63.

Heady, H.F. 1956. Changes in a California annual plant community induced by manipulation of natural mulch. Ecol. 37:798-812.

Heady, H.F., and R.D. Child. 1994. Rangeland ecology and management. Westview Press, Boulder, Colo.

Hyder, D.N. 1954. Forage utilization. J. Forest. 52:603-604.

Kleinbaum, D.G. and L.L. Kupper. 1978. Applied regression analysis and other multivariable methods. Duxbury Press, North Scituate MA.

Knight, D.H. 1973. Leaf area dynamics of a shortgrass prairie in Colorado. Ecol. 54:891-896.

LI-COR, Inc. 1993. LAI-2000 Plant Canopy Analyzer Operating Manual. LICOR, Inc., Lincoln Neb.

Parsons, A.J., E.L. Leafe, B. Collett, and W. Stiles. 1983a. The physiology of grass production under grazing. I. Characteristics of leaf and canopy photosynthesis of continuously-grazed swards. J. Appl. Ecol. 20:117-126.
Parsons, A.J., E.L. Leafe, B. Collett, P.D. Penning, and J. Lewis. 1983b. The physiology of grass production under grazing. II. Photosynthesis, crop growth and animal intake of continuously-grazed swards. J. Appl. Ecol. 20:127-139.

Reece, P.E., J.E. Brummer, R.K. Engel, B.K. Northup, and J.T. Nichols. 1996. Grazing date and frequency effects on prairie sandreed and sand bluestem. J. Range. Manage. 49-112-116.

SAS Institute, Inc. 1990. SAS/STAT ${ }^{\circledR}$ User's Guide, Version 6, Fourth Edition, Volume 2, Cary N.C.: SAS Institute Inc.

Schmutz, E.M. 1971. Estimation of range use with grazed-class photo guides. Ariz. Ext. Serv. Bull. A-73.

Sharp, L., K. Sanders, and N. Rimby. 1994. Management decisions based on utilization-Is it really management? Rangelands 16:38-40.

Smith, J.A., R.E. Oliver, and J.K. Berry. 1977. A comparison of two photographic techniques for estimating foliage angle distribution. Aust. J. Bot. 27:545-553.

Stringer, W.C., W.C. Bridges, B.W. Pinkerton, R.E. Chrestman, and J.S. Rice. 1995. Non-destructive measurements of canopy volume to estimate grazing activity. Crop Sci. 35:581-584.

Welles, J.M. and J.M. Norman. 1991. Instrument for indirect measurement of canopy architecture. Agron. J. 83:818-825. 